\title{
The Miracle in the World (The Second Translation of 721st-736th Poem of Tcheonzamun)
}

\author{
Hyeonhi Regina Park ${ }^{1}$, Jiah Anna Kim², Rosa Kim ${ }^{3}$, Alain Hamon ${ }^{4}$, Sohwa Therese \\ $\mathrm{Kim}^{5}$, Sangdeog Augustin Kim ${ }^{6 *}$
}

${ }^{1}$ Department of Elderly care and welfare, Joongbu University, Kumsan, Republic of Korea (ROK)

${ }^{2}$ Department d'Expertise Economique, Université de Paris-Est Creteil, Paris, France

${ }^{3}$ Specialité d'Economie politique, Ecole des Hautes Études en Sciences Sociales (EHESS) Paris, France

${ }^{4}$ Groupe scolaire iféa - Émilie du Châtelet, 92110 Clichy, France

${ }^{5}$ Specialité de Sciences Sociales, Ecole des Hautes Études en Sciences Sociales(EHESS). Paris, France

${ }^{6}$ Department of Companion animal and animal resources science, Joongbu University, Kumsan, ROK

\section{*Corresponding Author}

Sangdeog Augustin Kim

\section{Article History}

Received: 29.12.2020

Accepted: 16.01 .2021

Published: 22.01.2021

\begin{abstract}
The present researchers utilized the 16 Chinese characters in Tcheonzamun (The thousand character essay) from $721^{\text {st }}$ character to $736^{\text {th }}$ character. And its title is 'the miracle in the world'. This poem was already translated in Korean pronunciation by present researchers [1]. Therefore this is the second translation of $721 \mathrm{st}-736^{\text {th }}$ poem of Tcheonzamun. This is the present condition of Augustin. If I can keep my anger from the expression, I want to call it 'the miracle in the world'. And if I can forgive the person, I will call it the great miracle in the world. My Lord Jesus, give me, Augustin, a force to forgive other person whom I do not love, amen!
\end{abstract}

Keywords: Tcheonzamun (The thousand character essay), $721^{\text {st }}$ character to $736^{\text {th }}$ character, 'the miracle in the world'.

\section{INTRODUCTION}

The present researchers tried to translate the Tcheonzamun (The Thousand Character Essay) [2, 3]. Dallet [4] wrote that Tcheonzamun has been utilized in teaching Chinese characters to the children on Tchin dynasty, the first unified country in China during the year of BC 200 [4]. This poem was already translated in Korean pronunciation by present researchers [1]. Therefore this is the second translation of $721 \mathrm{st}-736^{\text {th }}$ poem of Tcheonzamun.

\section{Materials AND Methods}

The present researchers utilized the 16 Chinese characters in Tcheonzamun (The thousand character essay) from $721^{\text {st }}$ character to $736^{\text {th }}$ character. The researchers considered that these 16 letters composed a poem. And the poem is made of two parts; the first part is the first line, and the second part is composed of three lines; the second line, the third line and the fourth line [3]. The first part usually says the general fact, while the second part expresses the new and wider idea even including the first part.

\section{RESUlTS AND DiSCUSSION}

The next is considered as a poem. It is consisted of 16 letters from $721^{\text {st }}$ to $736^{\text {th }}$ characters of Tcheonzamun (The Thousand Character Essay). And its title is 'the miracle in the world'.

Copyright (C) 2021 The Author(s): This is an open-access article distributed under the terms of the Creative Commons Attribution 4.0 International License (CC BY-NC 4.0) which permits unrestricted use, distribution, and reproduction in any medium for noncommercial use provided the original author and source are credited. 
Number of Tcheonzamun (The thousand character essay) Chinese characters Pronunciation of Chinese character in Korean language Meaning of the line of 4 characters.

721-724 兩疏見機 Yang So Gyeon Gi If the two persons want each other to find the opportunity (機) to make bad of the other person (見), both of them (兩) might be separated (疏). Because it will be a good solution for this problem. Such a method is often used.

725-728 解組誰逼 Hae Zo Soo Pib No, it is not a good solution. If somebody (誰) will take a role in order to solve this problem (逼), the man or the woman will bind again (組) the biased condition of the two persons (解).

729-732 索居閑處 Saeg Keo Han Tcheo Am I willing to live (處) in the comfortable state (閑)? In this case, I must have an intention to find out the solution. How do I take such an answer? I have to search some explanation for the enemy (索) to whom I have deep hatred. And I must have (居) a tolerance for my enemy.

733-736 沈默寂察 Tchim Moog Zeog Yo If I want to be (察) in an easy state without trouble (寂), I must control (默) my bad temper to other people and/or my expression of the anger (沈).

This is the present condition of Augustin. If I can keep my anger from the expression, I want to call it 'the miracle in the world'. And if I can forgive the person, I will call it the great miracle in the world. My Lord Jesus, give me, Augustin, a force to forgive other person whom I do not love, amen!

\section{ACKNOWLEDGEMENTS}

We thank Mr Yeonghag Park and Mrs Hilye Sarah Kim, Mr Ilsoo Joseph Kim and Mrs Bohwa Kim, Ms Jieun Agatha Kim and Mr Kunjoo Daegon-Andrea Kim, Father Jean Blanc and Father Hifumi Iwazaki and Father Xavier Ha, Mrs Tamako Hayashi and Mr Yoshihiro Hayashi, Mrs Francine Tenaillon and Professor Nicolas Tenaillon, Father Gangseob Leo Eom OFM and the members of Daejeon Ludovich of Ordo Franciscanus Saecularis, Father Jungeob Paul Lee and the members of Daejeon Nae-dong Catholic Church, the student of Joongbu University and Groundwater well registering team in Korea Water Resources Corporation.

\section{REFERENCES}

1. Park, H.R., Kim, J.A., Kim, K.D.A., Kim, J.A., Kim, S.T., Kim, R., Hamon, A., Tenaillon, N., \& Kim, S.A. (2017a). The Tcheonzamun(the thousand character essay). Journal of Languages and Culture, 8(2): 14-17.

2. Park, H.R., Kim, J.A., Kim, K.D.A., Kim, J.A., Kim, S.T., Kim, R., Hamon, A., Tenaillon, N., \& Kim, S.A. (2017b). Ancient Koreans' petition to God in Tcheonzamun: The thousand character essay poem (641st to 656th letters). Journal of Languages and Culture, 8(6): 79-84.

3. Park, H.R., \& Kim, S.A. (2017). Don't be an idiot! Fight! with the apparent title of You must write it on your words as historical records by your own hand - Translation of the poem on Tcheonzamun (the book of The Thousand Character Essay) from 673rd to 688th both by using Chinese characters and through Korean pronunciation. Journal of Languages and Culture, 8(3): 24-27.

4. Dallet, C.H. (1874). Histoire de l'Eglise de Corée (History of Korean Catholic Church). Victor Palme. Paris. France, 11-99.

CITATION: Hyeonhi Regina Park et al (2021). The Miracle in the World (The Second Translation of 721st-736th Poem of Tcheonzamun). South Asian Res J Human Soc Sci, 3(1): 1-2. 